\title{
THE PATHOGENESIS OF EXPERIMENTAL CHOLERA
}

\author{
H. K. GHosh* \\ Department of Bacteriology, University of Edinburgh
}

\section{Plate XXXVII}

IT has recently been claimed that two experimental models closely simulate natural cholera. De and Chatterje (1953) induced accumulation of watery fluid in the ileum of adult rabbits by injecting virulent vibrios into loops between ligatures in vivo. Dutta and Habbu (1955) observed a fatal diarrhoea in suckling rabbits after injection of cholera vibrios into the small intestine. The pathology of these experimental infections has been studied by several workers without any general agreement being reached on the exact changes and their relationship to natural cholera (Burrows, 1968).

The early phase of infection-perhaps the most critical stage in hostparasite interactions (Meynell and Maw, 1968)-has received scant attention. Hence the following integrated morphological, bacteriological, histopathological and biochemical studies were undertaken to examine the evolution of experimental cholera in rabbits and guinea-pigs (Cavia porcellus) with a view to correlating the findings with those in natural cholera. The study also clarified some of the existing confusions by enabling distinction of some secondary changes from primary lesions.

\section{MATERIALS AND METHODS}

General. The general procedures were according to Cruickshank (1965). The usual diluent for cultures was peptone saline made by adding $1 \mathrm{vol}$. peptone water to $10 \mathrm{vol}$. saline, $p \mathrm{H} 7 \cdot 0-7 \cdot 2$.

Vibrio strains. Freeze-dried Vibrio cholerae and V. eltor strains, received from different laboratories, were cultivated on meat-extract agar plates. After biochemical and serological verification each was passaged in a rabbit loop. A typical colony from loop fluid was grown on an agar slope for $16-18 \mathrm{hr}$ at $37^{\circ} \mathrm{C}$ and freeze-dried by Greaves' method in $c .30$ ampoules, which were then stored at $2^{\circ}-4^{\circ} \mathrm{C}$. The challenge dose was prepared every time from an ampoule by growing on an agar slope. The overnight growth was suspended in diluent to match visually 5 IU opacity (Maaløe, 1955), corresponding in our hands to a total count of $(6-14) \times 10^{8}$ (mean 109) cells per $\mathrm{ml}$ as determined with a Helber chamber, and a colony count of $(1 \cdot 4-8 \cdot 0) \times 10^{8}$ (mean $\left.5 \times 10^{8}\right)$ per $\mathrm{ml}$ as determined from duplicate spread plates. The suspension was further diluted to contain the desired infective dose in $0.2 \mathrm{ml}$ for a baby rabbit and in $0.5 \mathrm{ml}$ for a loop. The dose was injected through a $27-\mathrm{SWG}$ needle, bent at $120^{\circ}$ at the tip, attached to a tuberculin syringe. Simultaneously a colony count was made from $0 \cdot 2 \mathrm{ml}$ of the inoculum material.

Most experiments were performed with three strains. V. cholerae $12 \mathrm{r}$, an Ogawa strain from Dacca, East Pakistan, was typical in all respects. V. cholerae 834 (Ogawa), also from

Received 28 Oct. 1969; accepted 21 Feb. 1970.

* Present address: Jabatan Bakterialogi, Universiti Malaya, Kuala Lumpur.

J. MED. MICROBIOL.-VOL. 3 (1970) 
Dacca, and 569B (Inaba), probably isolated in Calcutta (Shrivastava and White, 1947), agglutinated fowl red cells even after rabbit passage.

Animals. 8-12-mth-old rabbits and young guinea-pigs of 250-400 $\mathrm{g}$ were obtained from the Small Animal Breeding Station of the University. Treatments within a batch and in loops of an animal were allotted on the randomised block principle. They were kept in wire-mesh cages, the rabbits singly and the guinea-pigs in groups of 4-6, and fed on commercial pellets supplemented thrice weekly with greens. Water was allowed freely even to starved animals. The suckling rabbits were bred in the laboratory from one Black-pointed California family. A 10-12-day-old baby rabbit weighed $150-350 \mathrm{~g}$. On the day of challenge each was weaned in a sheet-metal mouse cage padded with Cellosene.

Intestinal loops. A series of up to eight loops was prepared in an adult rabbit under Nembutal anaesthesia by applying ligatures in situ at $10-\mathrm{cm}$ intervals starting about $40 \mathrm{~cm}$ from the ileocaecal junction and proceeding anteriorly. Peristalsis precluded direct measurements. Necropsies showed that the straight mesenteric vessels entered the gut at $0.5-\mathrm{cm}$ intervals, and that the tip of the appendix was anchored to the ileum $c .25 \mathrm{~cm}$ from the ileocaecal valve. These measurements were used as guides. The infective doses were injected into alternate loops. Diluent only was injected into the intermediate segments. The gut was carefully replaced, and the abdomen was closed in two layers. Animals were killed at intervals with ether for histological examination, otherwise with intravenous magnesium sulphate. In guinea-pigs 8 -cm loops proved more satisfactory.

Baby rabbits were inoculated as detailed elsewhere (Ghosh, 1969). Briefly, the inoculum was injected into the duodenum exposed in situ in animals under ether anaesthesia. They were fed on cow's milk by catheter and neither gained nor lost weight till killed. Sick animals were observed till death, or killed the day after cessation of diarrhoea. Some moribund animals were killed with a blow on the head and examined at necropsy immediately. The onset of diarrhoea and death were reckoned to have occurred at the midpoint of the last two observations, which were made at intervals not exceeding $10 \mathrm{hr}$.

In all animals necropsy was carried out aseptically; the abdomen was opened last. Specimens were analysed chemically, and cultured for vibrios and any incidental pathogens. Tissues were fixed in formol-saline for paraffin sections and in osmic acid for electron microscopy (Patnaik and Ghosh, 1966). Succinic dehydrogenase activity of intestinal lining cells was studied in snap-frozen sections by the neotetrazolium black method.

For estimating the total colony count in a diarrhoeic baby rabbit the intestine was removed by severing the mesentery between ligatures on the duodenum and the rectum; it was then placed in a petri dish and slit along its length. The drained fluid was collected with a graduated pipette. When there was little fluid, the segment removed was flushed with $15 \mathrm{ml}$ diluent introduced through the duodenum, which was then expelled through the rectal end by injecting air; the volume of fluid recovered was noted.

Biochemical assays. The concentrations of sodium and potassium were estimated in an EEL portable flame photometer, that of carbon dioxide in a Van Slyke apparatus, and that of chloride by silver nitrate titration. Infected fluids were saturated with Analar chloroform, kept at room temperature $\left(18^{\circ}-22^{\circ} \mathrm{C}\right)$ for $30 \mathrm{~min}$., and then centrifuged at $2000 \mathrm{~g}$ for $30 \mathrm{~min}$. at room temperature.

\section{RESULTS}

\section{Suckling rabbits}

Course of infection. Vibrio cholerae $12 \mathrm{r}$ was injected in doses from 1 to $10^{8}$ colony-forming units (CFU) into the duodenum of 52 normal baby rabbits. Thirty-seven of these died with overt diarrhoea; five died with watery fluid in the bowel; nine remained well. Another, challenged with c. $20 \mathrm{CFU}$, recovered on the 3 rd day after overnight diarrhoea.

Litters varied considerably in susceptibility. Both incubation period and interval to death were generally related to the size of challenge (figs. 1 and 2). 
Death occurred 8-36 $\mathrm{hr}$ after the injection, except in three animals that died in 56,82 and $90 \mathrm{hr}$ after the belated onset of diarrhoea at 48,58 and $72 \mathrm{hr}$

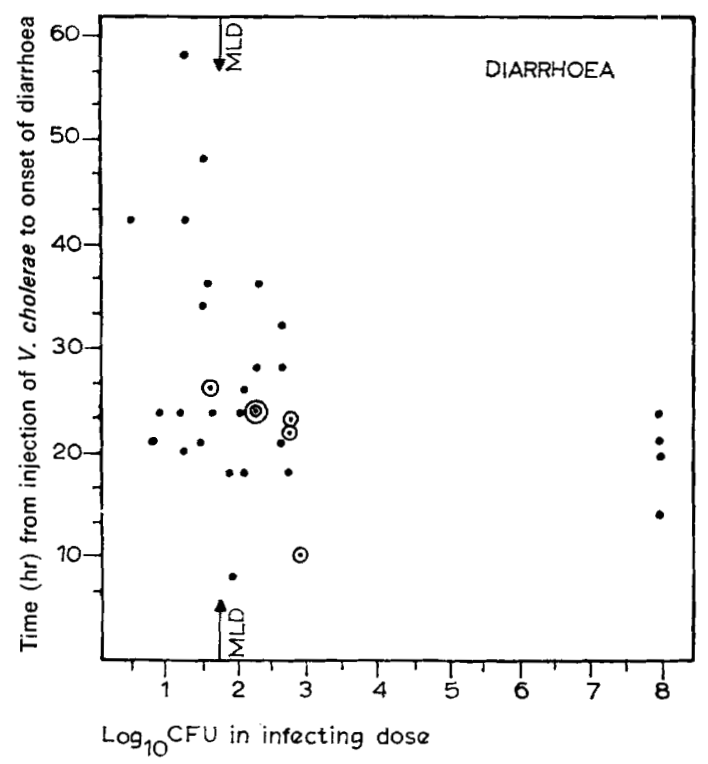

FIG. 1.-Scatter diagram showing relation between challenge doses of Vibrio cholerde $12 \mathrm{r}$ and the onset of diarrhoea in baby rabbits. In this and subsequent figures $\odot$ means two, and (๑) three coincident points.

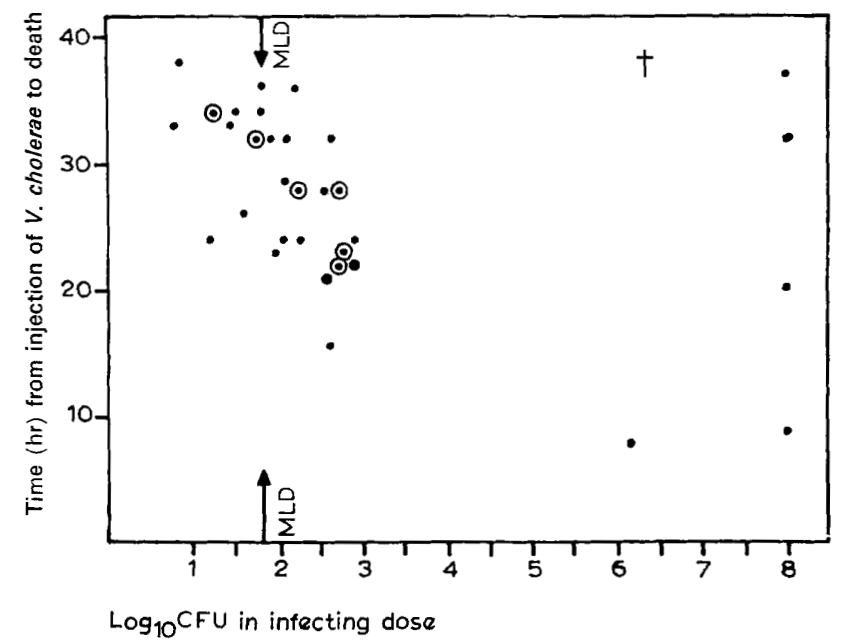

FIG. 2.-Relation between challenge doses and survival periods in the same series of rabbits as in fig. 1 .

respectively. Infection with $60 \mathrm{CFU}$ or more always killed within $34 \mathrm{hr}$. Diarrhoea usually appeared less than $8 \mathrm{hr}$ before death: only two rabbits showed it for over $24 \mathrm{hr}$. The stool was watery with a greenish tinge, usually 
dribbling slowly from the anus. No animal lost weight, probably because of the continued feeding. About 6-12 hr before death the animals became cold and limp, and the abdomen became a little distended and felt doughy.

All four siblings infected each with $5 \times 10^{3} \mathrm{CFU}$ of $V$. cholerae $569 \mathrm{~B}$ were dead on the third morning with terminal diarrhoea.

Gross pathological changes. The findings of post-mortem bacteriological and biochemical examinations of the 52 animals were qualitatively similar to those of 109 passively immunised baby rabbits challenged with $V$. cholerae $12 \mathrm{r}$. All 161 are considered together. Of these, 73 died of cholera; five others were killed a day after cessation of diarrhoea but had watery fluid in the intestines. Necropsy was done immediately after death in 18 . Six rabbits, besides the 161 , were killed at predetermined intervals of 6-28 hr in order to study the early stages of infection.

The gross changes in choleraic rabbits were those of tissue dehydration with fluid accumulation in the intestines. An early rigidity contrasted with the agonal limpness. Parietal tissues were dry and sticky. The viscous blood flowed slowly into pipettes, lysed easily and yielded little serum. The solid viscera looked normal both grossly and microscopically, except for occasional congestion. The urinary bladder was full in most healthy rabbits and in 68 per cent. of choleraic rabbits.

Hyperaemia limited to the ileum, frequently described in human victims, was exceptional. In a few rabbits all abdominal viscera were congested, most markedly the liver, the renal medulla and the distal ileum-a phenomenon not uncommon in the control animals. The stomach, jejunum and gall bladder almost invariably looked normal. The distal $10-20 \mathrm{~cm}$ of the ileum contained a little turbid fluid. The caecum and colon were distended with bile-stained watery fluid, usually 4-6 ml per $100 \mathrm{~g}$ body weight, but in one rabbit amounting to $7 \mathrm{ml}$ per $100 \mathrm{~g}$ body weight. The colonic fluid invariably had faecal debris that sedimented rapidly on standing, leaving an almost water-clear fluid. The characteristic odour and grey opalescence of ricewater stools were lacking.

Histological changes. The tissues of six normal and eight choleraic rabbits were fixed immediately after death. The microscopic changes are limited to the distal small intestine, apart from some congestion of the solid viscera, duodenum and jejunum in one rabbit. The general architecture of the ileum is maintained (fig. 3). The columnar epithelium lacks the mucin layer on the surface, but has an intact brush border and stains normally. Vibrios are adherent to the brush border, but never invade more deeply. Many goblet cells are well filled with mucin. The dilated lacteals and oedematous mucosa and submucosa contain proteinaceous deposits. Small blood vessels are dilated and stuffed with red cells, suggesting haemoconcentration. Such changes are pronounced in only two rabbits. The caecum looks normal in four. In two others the lining mucus is lost and there is some congestion in the mucosa. None shows adherent vibrios.

Bacteriological findings. Smears of the contents of duodenum and proximal small intestine occasionally showed a few Gram-positive bacilli and streptococci together with Gram-negative bacilli, as in healthy animals. Smears 
TABLE I

Isolation rate of Vibrio cholerae $12 \mathrm{r}$ at necropsy from baby rabbits given $V$. cholerae $12 r$ intraduodenally

\begin{tabular}{|c|c|c|c|}
\hline \multirow{3}{*}{ Site } & \multicolumn{3}{|c|}{ Isolation rate of $V$. cholerae (animals positive/animals examined) in } \\
\hline & \multirow{2}{*}{ apparently healthy animals } & \multicolumn{2}{|c|}{ choleraic animals at } \\
\hline & & early necropsy & delayed necropsy \\
\hline $\begin{array}{l}\text { Blood } \quad: \\
\text { Bile . } \\
\text { Spleen* : }\end{array}$ & $\begin{array}{c}0 / 10 \\
\ldots\end{array}$ & $\begin{array}{l}0 / 19 \\
0 / 13 \\
0 / 4\end{array}$ & $\begin{array}{c}3 / 32 \\
10 / 36 \dagger \\
5 / 5 \dagger\end{array}$ \\
\hline $\begin{array}{l}\text { Contents of : } \\
\text { Stomach } \\
\text { Duodenum } \\
\text { Mid-ileum } \\
\text { Distal ileum } \\
\text { Caecum }\end{array}$ & $\begin{array}{c}\ldots \\
\cdots \\
\cdots \\
4 / 32\end{array}$ & $\begin{array}{c}0 / 7 \\
6 / 18 \\
15 / 17 \\
18 / 18 \\
23 / 23\end{array}$ & $\begin{array}{c}0 / 7 \\
5 / 11 \\
9 / 9 \\
14 / 14 \\
54 / 57\end{array}$ \\
\hline
\end{tabular}

* Blood sterile.

$\dagger$ Difference between results for early and late necropsies statistically significant $(\mathbf{P}<0.01)$.

TABLE II

Distribution of $V$. cholerae $12 r$ at necropsy in normal baby rabbits given that organism intraduodenally

\begin{tabular}{|c|c|c|c|c|c|c|c|c|c|}
\hline \multirow{2}{*}{$\begin{array}{c}\text { Serial } \\
\text { no. }\end{array}$} & \multirow{2}{*}{$\begin{array}{c}\text { Weight } \\
\text { (g) }\end{array}$} & \multicolumn{2}{|c|}{$\begin{array}{c}\text { Number of vibrios } \\
\text { (CFU) }\end{array}$} & \multirow{2}{*}{$\mathrm{T}^{*}$} & \multirow{2}{*}{$\begin{array}{l}\text { Volume of } \\
\text { intestinal } \\
\text { fluid }(\mathrm{ml}) \dagger\end{array}$} & \multicolumn{4}{|c|}{ Cultures $\ddagger$ from } \\
\hline & & given & recovered & & & duodenum & mid-ileum & $\begin{array}{l}\text { distal } \\
\text { ileum }\end{array}$ & colon \\
\hline $\begin{array}{l}\text { R212 } \\
\text { R287 } \\
\text { R245 } \\
\text { R252 } \\
\text { R288 } \\
\text { R253 } \\
\text { R244 } \\
\text { R289 } \\
\text { R246 } \\
\text { R250 } \\
\text { R251 } \\
\text { R138 } \\
\text { R278 }\end{array}$ & $\begin{array}{l}356 \\
220 \\
160 \\
284 \\
240 \\
285 \\
212 \\
210 \\
156 \\
216 \\
212 \\
200 \\
216\end{array}$ & $\begin{aligned} & 15 \times 10^{5} \\
& 10^{2} \\
& 6 \times 10^{3} \\
& 57 \times 10^{2} \times 10^{2} \\
& 57 \times 10^{2} \\
& 23 \times 10 \\
& 10^{2} \\
& 6 \times 10^{3} \\
& 16 \times 10 \\
& 16 \times 10 \\
& 17 \times 10 \\
& 16 \times 10^{2}\end{aligned}$ & $\begin{array}{l}42 \times 10^{6} \\
52 \times 10^{3} \\
\ldots \\
84 \times 10^{5} \\
\ldots \\
84 \times 10^{6} \\
62 \times 10^{8} \\
10^{7} \\
62 \times 10^{7} \\
56 \times 10^{2} \\
72 \times 10^{8} \\
23 \times 10^{8} \\
98 \times 10^{8}\end{array}$ & $\begin{array}{r}8 \mathrm{hr} \\
12 \mathrm{hr} \\
12 \mathrm{hr} \\
12 \mathrm{hr} \\
18 \mathrm{hr} \\
18 \mathrm{hr} \\
20 \mathrm{hr} \\
24 \mathrm{hr} \\
24 \mathrm{hr} \\
28 \mathrm{hr} \\
28 \mathrm{hr} \\
34 \mathrm{hr} \\
124 \mathrm{hr}\end{array}$ & $\begin{array}{c}7 \frac{1}{2} \\
\text { Nil } \\
\text { Nil } \\
\text { Nil } \\
\text { Nil } \\
5 \frac{1}{2} \\
8 \\
1 \frac{1}{2} \\
11 \\
10 \\
6 \frac{1}{2} \\
4 \frac{1}{2} \\
10\end{array}$ & $\begin{array}{l}0 \\
0, \mathrm{C}+ \\
0, \mathrm{C}+ \\
0 \\
0, \mathrm{C}- \\
0 \\
0 \\
0, \mathrm{C}- \\
+, \mathrm{C}+ \\
2+ \\
0 \\
2+\end{array}$ & $\begin{array}{l}2+ \\
0, \mathrm{C}+ \\
2+, \mathrm{C}- \\
0 \\
0, \mathrm{C}+ \\
2+ \\
+, \ldots \\
+, \mathrm{C}_{-} \\
2+, \mathrm{C}+ \\
0+ \\
2+\ldots\end{array}$ & $\begin{array}{l}2+, \\
+, \mathrm{C}+ \\
2+, \mathrm{C}- \\
0, \mathrm{C}- \\
2+, \mathrm{C}+ \\
2+ \\
2+ \\
+, \mathrm{C}+ \\
2+, \mathrm{C}+ \\
2+ \\
2+ \\
2+ \\
2+\end{array}$ & $\begin{array}{l}2+ \\
2+, \mathrm{C}+ \\
2+, \mathrm{C}+ \\
2+, \mathrm{C}+ \\
2+, \mathrm{C}+ \\
2+, \mathrm{C}+ \\
2+, \\
2+, \mathrm{C}+ \\
2+, \mathrm{C}+ \\
2+ \\
2+ \\
2+ \\
2+\end{array}$ \\
\hline
\end{tabular}

Necropsy was performed immediately after death.

* Time from vibrio inoculation to death.

$\uparrow$ Most of the fluid in caecum with some in distal ileum.

$\$ 0,+, 2+=$ No growth to heavy growth of vibrio; $\mathrm{C}+=$ coliforms present, $\mathrm{C}-=$ coliforms absent. 
from lower ileum usually contained vibrios alone. Colonic fluid contained mostly vibrios with some commensals. Epithelial cells, pus cells and red cells were rare. The results of culture from 23 immediate and 57 delayed necropsies are shown in table I separately in view of the rapid dissemination of bacteria in tissues after death. The caecal contents of 12 per cent. of healthy experimental animals contained a few vibrios. In choleraic animals vibrios were abundant in the colon and lower ileum, and usually also in the mid-ileum. Invasion of the proximal gut was a late phenomenon (table II). Coliforms grew from all

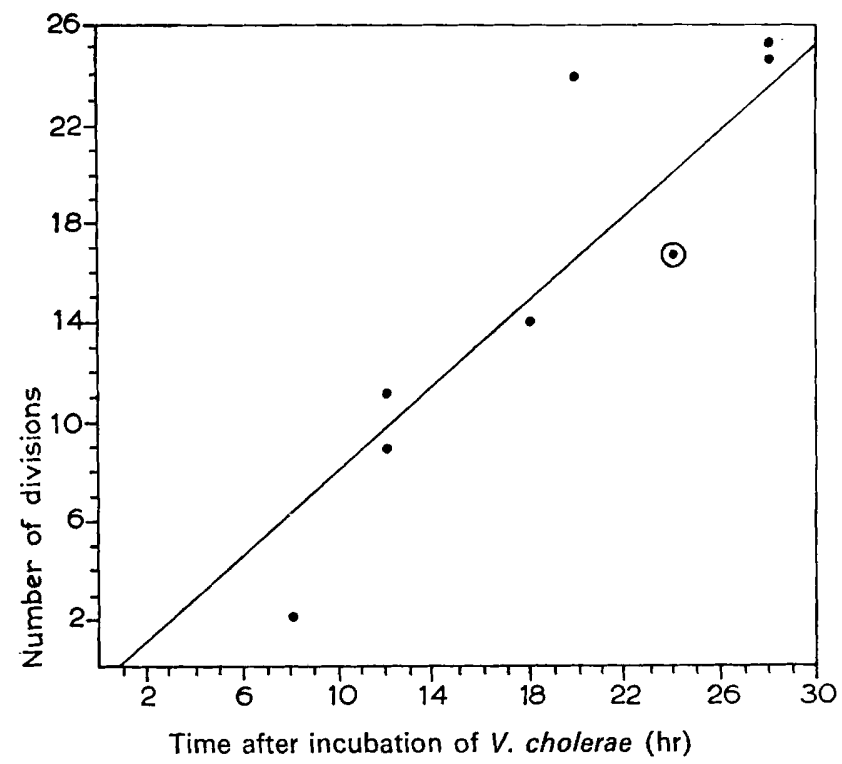

FIG. 4.-Growth of $V$. cholerae $12 \mathrm{r}$ in baby rabbit, from data of table II. Number of divisions $=\log _{2} C_{\mathbf{T}} / C_{0} ; C_{0}$ and $C_{T}$ are the colony counts of inoculum and bowel washings respectively. Line fitted by least-squares method $(b=0.87 ; 7$ d.f.; $t=4.0 ; P<0.01)$. On infection with 5-10 MLD there was a lag period of $c .1 \mathrm{hr}$ followed by steady growth for c. $30 \mathrm{hr}$, and then a stationary phase coincident with appearance of fluid in gut lumen. Loss from death of vibrios in this short time was ignored.

specimens from colon and terminal ileum and, in later specimens, also from the proximal ileum. They were profuse throughout the intestines, including the duodenum, of the five rabbits recovering from diarrhoea, but vibrios were found in their terminal ileum and colon only.

Apparently on inoculation the vibrios were propelled to the distal ileum, where they multiplied steadily after a brief lag period (fig. 4) to attain a population of $c .10^{9} \mathrm{CFU}$, the mean doubling time being about twice that in stationary broth tubes. Fluid then began to accumulate and run into the colon. It is doubtful whether there was much growth of vibrios in the free fluid, which contained only $10^{6}-10^{8} \mathrm{CFU}$ per ml. Gradually anterior parts of the small gut were invaded. During recovery the vibrios were eliminated from the anterior parts first, and last from the caecum. By contrast, when $c .10^{8} \mathrm{CFU}$ Serratia marcescens were injected in each of two siblings only $6 \times 10^{6}$ and 


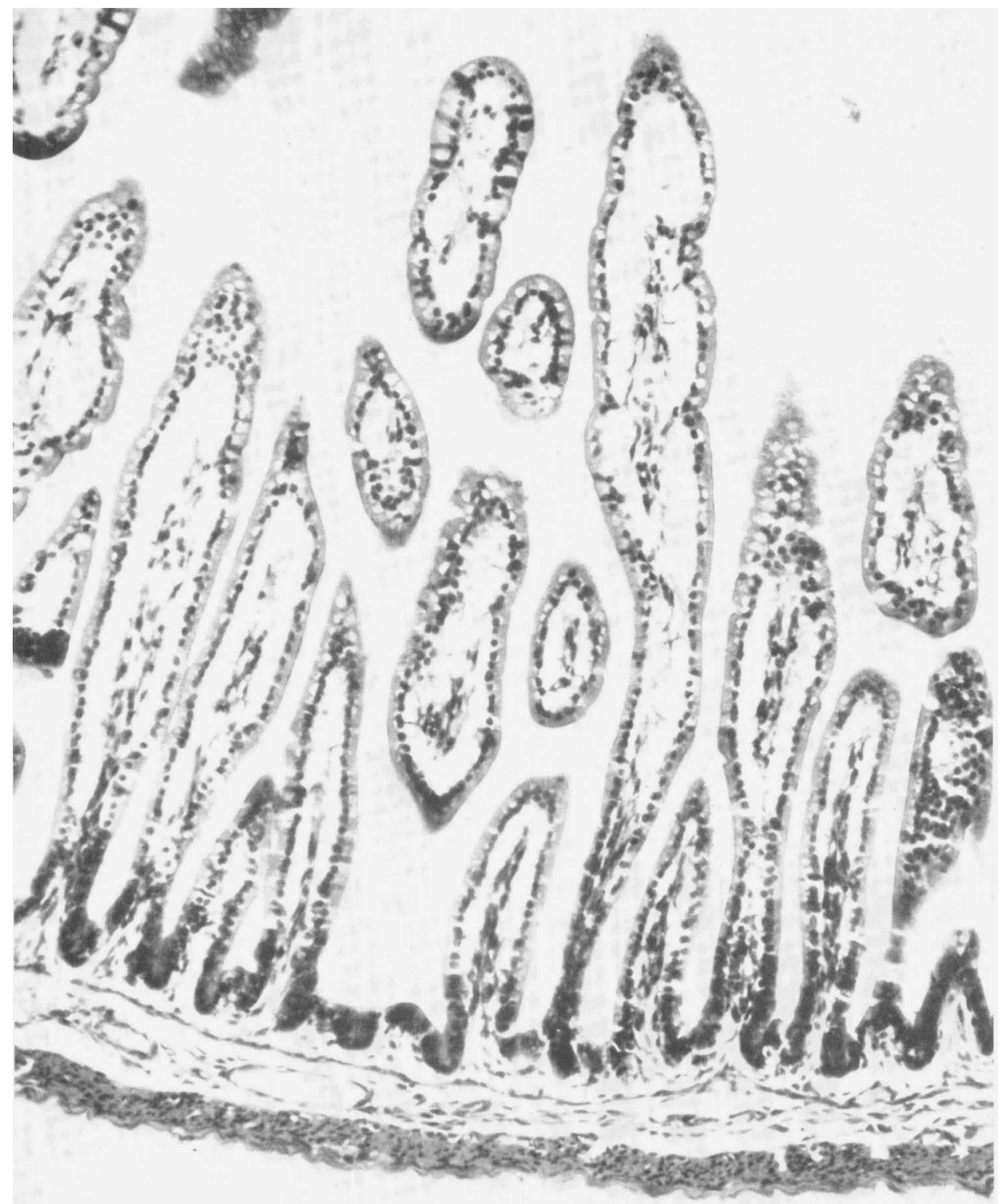

FIG. 3.- Distal ileum of baby rabbit no. R244 killed $20 \mathrm{hr}$ after infection (table II). Normal architecture with marked subepithelial oedema. Mucin in goblet cells appears dark. Alcian bluehaematoxylin-eosin. $\times 85$. 
PATHOLOGY OF EXPERIMENTAL CHOLERA

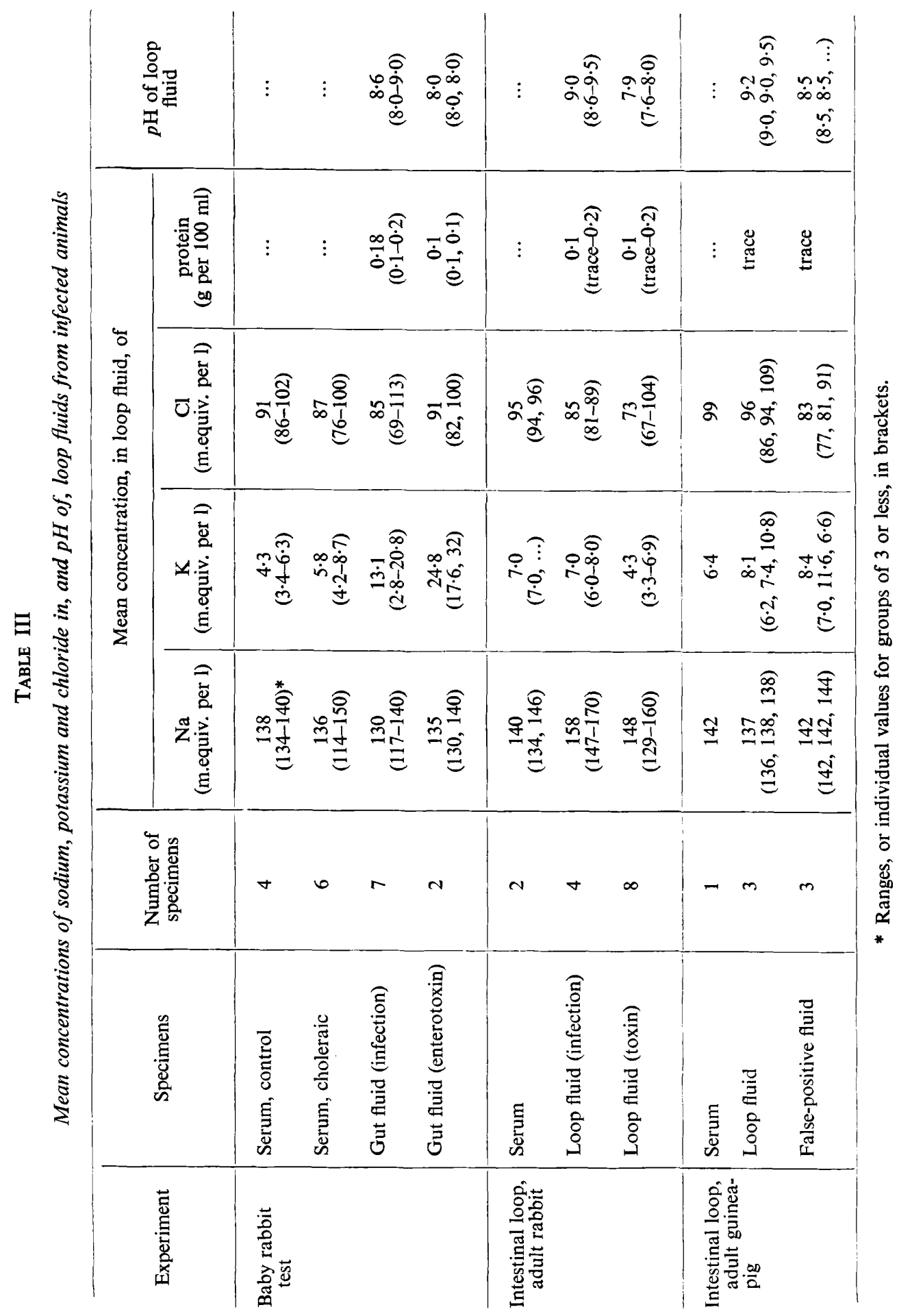


$25 \times 10^{6} \mathrm{CFU}$ were recovered $12 \mathrm{hr}$ later, and then exclusively from the caecum.

Sanerelli's (1921) observation on a retrograde asymptomatic infection could not be confirmed. About $10^{8} \mathrm{CFU}$ of $V$. cholerae $12 \mathrm{r}$ were introduced through a catheter inserted $4-5 \mathrm{~cm}$ through the anus of two rabbits; no vibrios could be recovered from the gut or bile 2 days later.

\section{TABLE IV}

Proportion of baby rabbits dying after intraduodenal injection of $V$. cholerae $12 r$, or of adult animals showing accumulation of loop fluid $18 \mathrm{hr}$ after injection of $V$. cholerae into the loop

\begin{tabular}{|c|c|c|c|}
\hline \multirow{3}{*}{$\begin{array}{c}\text { Number of } V \text {. cholerae } \\
12 \mathrm{r}(\mathrm{CFU}) \\
\text { in inoculum }\end{array}$} & \multicolumn{3}{|c|}{ Incidence of } \\
\hline & \multirow{2}{*}{ death in baby rabbits } & \multicolumn{2}{|c|}{ fluid in } \\
\hline & & rabbit intestinal loops & guinea-pig intestinal loops \\
\hline $\begin{array}{c}0 \\
2-9 \\
10-29 \\
30-50 \\
60-80 \\
100-250 \\
300-800\end{array}$ & $\begin{array}{c}0 / 18 \\
4 / 7 \\
2 / 3 \dagger \\
4 / 10 \\
7 / 7 \\
11 / 11 \\
11 / 11\end{array}$ & $\begin{array}{l}0 / 47 \\
\ldots \\
\ldots \\
\ldots \\
\ldots \\
0 / 2 \\
\ldots\end{array}$ & $\begin{array}{c}38 / 127 \\
9 / 12 \\
11 / 15 \\
\ldots \\
9 / 10 \\
59 / 62 \\
\ldots\end{array}$ \\
\hline $\begin{array}{l}10^{3 *} \\
10^{4} \\
10^{5} \\
10^{6} \\
10^{7}\end{array}$ & $\begin{array}{l}\ldots \\
\cdots \\
\cdots \\
\cdots \\
\cdots\end{array}$ & $\begin{array}{c}0 / 5 \\
2 / 8 \\
15 / 16 \\
14 / 14 \\
14 / 14\end{array}$ & $\begin{array}{l}3 / 5 \\
4 / 4 \\
4 / 4 \\
3 / 4 \\
3 / 3\end{array}$ \\
\hline
\end{tabular}

* Doses of $10^{3} \mathrm{CFU}$ and above are mean values.

$\uparrow$ The third rabbit had diarrhoea but recovered.

Biochemical changes (table III). Serum sodium and chloride concentrations were within normal limits, but potassium levels were distinctly higher. The gut fluid was abnormally alkaline (normal $p \mathrm{H} c .7$ in caecum and 8 in ileum). Protein was below $0.2 \mathrm{~g}$ per $100 \mathrm{ml}$. The ranges of sodium and chloride concentrations approached those in serum, but the potassium levels greatly exceeded the corresponding serum levels in five out of seven animals.

\section{Loops in rabbits and guinea-pigs}

The gross, microscopic and ultramicroscopic changes in rabbits have already been described (Patnaik and Ghosh). The progressive changes during the first $10-12 \mathrm{hr}$ were essentially similar to those in baby rabbits; in general they were most characteristic 6-8 hr after inoculation of 1-100 minimum effective doses of $V$. cholerae 12r. Later, increased luminal pressure caused necrosis. The biochemical changes in loop fluids were also similar (table III). 
Curiously, the fluids that collected proximal to the ligatures and in the falsepositive loops of guinea-pigs had somewhat similar compositions. Succine dehydrogenase, indicative of general cell metabolism, instead of being localised in the brush border, was distributed diffusely through the columnar epithelium in both the control and infected loops $6 \mathrm{hr}$ after challenge. Smear and culture of loop fluids invariably showed some commensals, but vibrios predominated with a count of (1-6) $\times 10^{8} \mathrm{CFU}$ per $\mathrm{ml}$. No vibrio was isolated from the blood, bile and control loops of 15 rabbits killed before necrosis of the loops occurred.

Guinea-pigs proved less satisfactory. Operative mortality was high till general anaesthesia was abandoned in favour of Nembutal basal anaesthesia with local procaine infiltration. About a third of the control loops swelled up so giving false-positive reactions. Thirty-five per cent. of control loops, normal in appearance or swollen, contained cholera vibrios in small numbers. These have been excluded from the data. Sometimes the loop fluid was chylous or faecal. Blood culture was positive for vibrios in five out of 13, and bile in six of 22 guinea-pigs.

Guinea-pigs could usually be infected with less than $10 \mathrm{CFU}$ of $V$. cholerae 12r. Rabbits resisted doses below $10^{3} \mathrm{CFU}$, a consistent infection requiring c. $10^{5} \mathrm{CFU}$ for each loop (table IV).

\section{Discussion}

The controversy on the pathology of experimental cholera has centred around the following questions: (a) whether the infection in baby rabbits affects mainly the colon or, as in man, the ileum; $(b)$ whether there is inflammation or necrosis of the affected gut; $(c)$ whether vibrios invade the tissues except terminally, and $(d)$ how closely the pathological changes in baby rabbits and adult rabbit loops resemble each other and the human disease.

It is evident that the basic processes in loops and baby rabbits are analogous when allowance is made for operational artefacts.

It has been asserted that colitis occurs in baby rabbits infected with $V$. cholerae mainly because the bulk of the fluid lies in the colon, and the proximal small intestine remains free of vibrios. The present histological studies suggest that the colon acts merely as a receptacle into which fluid drains from the ileum. The anterior small intestine is affected later, presumably from backflow of fluid under tension coupled with peristaltic irregularity that could, in turn, result from the severe change in extracellular potassium level. Oral intubation of the duodenum has usually yielded sterile samples in patients passing $V$. cholerae in their stools (Gangarosa et al., 1960).

Although Metchnikoff (1894) recorded loss of intestinal lining only as a terminal event in baby rabbits, Issaeff and Kolle (1894), Sanarelli (1921) and Dutta and Habbu (1955) recorded it regularly. In our series ulceration was never observed, which agrees with the findings of Fresh, Versage and Reyes (1964) who have, moreover, induced necrosis in loops simply by keeping them distended with saline. 
The enteric congestion that is seen in dead baby rabbits has often been emphasised, no doubt because of its resemblance to the pinkish hue described in the intestines of cholera victims. The distribution of the sporadic diffuse visceral congestion seen in our series accorded with that in any hypovolaemic shock (Scotti, 1966). On the other hand, the microscopically detectable vascular changes limited to the mucosa of the distal ileum of baby rabbits and in loops were the earliest visible host reaction. This has been confirmed by electron microscopy (Patnaik and Ghosh, 1966). The low protein concentration in luminal fluid is easily explained by the failure of plasma proteins to pass across the intact mucosal lining. The excess protein was drained away by the dilated lacteals and venules, and partly deposited in the stroma. Keusch, Atthasampunna and Finkelstein (1967) have shown that an iron-dextran complex injected intravenously into choleraic baby rabbits leaked out of the intestinal vessels, but could not pass into the gut lumen. The functional integrity of the lining epithelium is also shown by the frequent disparity in electrolyte concentrations in blood and intestinal fluid of individual animals.

The abnormal distribution of succinic dehydrogenase in the mucosal epithelium in early stages of both control and infected loops resulted probably from surgical trauma, whereas the decrease in alkaline phosphatase and leucine aminopeptidase in advanced lesions of patients and rabbits noted by Fresh et al. might well have been the results of disease. Trauma, including prolonged exposure to air, may also account for the generalised enteric congestion, cellular infiltration and emptying of goblet cells reported by some workers in loops and in baby rabbits. The healthy human appendix removed incidentally may show similar changes (Horn, 1966). It is relevant that Finkelstein, Norris and Dutta (1964) observed cellular infiltration in suckling rabbits given $V$. cholerae intestinally at laparotomy, but not when they were challenged by mouth. The absence in our series of such changes in baby rabbits suffering or recovering from diarrhoea lasting 2-3 days excludes intestinal inflammation as an essential feature. This must be considered characteristic of cholera, since baby rabbits with experimental salmonella enteritis do show intense cellular infiltration with focal necrosis (Ghosh, 1969). Emptying of goblet cells is perhaps the most sensitive indicator of irritation of intestinal mucosa (Florey, 1933), and is a feature conspicuously absent in experimental cholera.

The degree of correspondence between the natural disease and the experimental infections is hard to assess until there is greater certainty about the nature of primary lesions in patients, for these are not easily distinguished from secondary changes, even in early necropsies. The usually described cloudy degeneration, visceral oedema and intestinal ulceration may follow simple shock, as in cardiac failure (Marston, 1962). Several workers (the earliest was Cohnheim, 1889) have described intact mucosal lining in necropsies on cases of cholera. The findings of Goodpasture (1923) on fresh bodies were virtually identical with those in baby rabbits described here. Peroral biopsies (Gangarosa et al.; Fresh et al.) also reveal an intact mucosal lining, with the mild oedema, congestion and cellular infiltration known to be quite common in healthy persons in the tropics (Sprinz et al., 1962). The relevance of such 
biopsies has been questioned because the published photographs suggest that they were from the upper intestines. Vibrios were also absent in aspirates from the biopsy level, although the patients were passing vibrios in the stools. The physiological evidence presented by these authors is more convincing. The low protein concentration in the stool was matched by failure of 131I-polyvinylpyrrolidone (molecular weight $c$. 40,000) injected intravenously to appear in stool in abnormal amounts.

Bacteriaemia in cholera has never been demonstrated in man though vibrios can be detected occasionally in bile and urine at necropsy. Burrows, Elliot and Havens (1947) isolated vibrios from the spleen of orally infected symptomless guinea-pigs. We could detect them in bile or spleen, even when the duodenum and blood were sterile, only in delayed necropsies on babies. This is hard to explain. However, large inert particles are known to pass the intact intestinal lining of mammals-the Herbst effect (Volkheimer, 1965). Conceivably, the increased number of vibrios entering the bloodstream of a collapsed host could escape the normal vibriocidal processes and so be trapped in the spleen and liver, multiplying rapidly after death.

The observed biochemical changes in my experimental animals also agreed with those reported in man (Lindenbaum et al., 1965). However, the serous gut fluid in rabbits is visibly different from the gruelly ricewater stool of severe cholera. The peculiarity of such a stool has never been explained. Does ricewater stool contain a high concentration of polysaccharides derived from the breakdown of bacterial cells and excessive epithelial mucin? The answer may be linked to that of another problem, viz., why the stool is isotonic with plasma although it contains little protein and no excess of the total known electrolytes.

The pathological changes indicated that vibrios must liberate some toxin acting locally on the lining epithelium. De (1959) reported a heat-labile enterotoxin in culture filtrates that reproduced loop lesions. In our animals an exotoxin could be readily demonstrated in the gut fluid of loops and baby rabbits, when it was sterilised by saturation with chloroform at room temperature for an hour and then centrifuged to remove the cells (table V). Baby rabbits given the toxin intra-intestinally died in about the same time as infected ones. The activity was stable for months at $2^{\circ}-4^{\circ} \mathrm{C}$. The toxin was harmless to Swiss mice and white rats when given intraperitoneally in doses of 0.5 and $2.0 \mathrm{ml}$ respectively. Fluid induced by toxin was itself non-toxic. This toxin was not neutralised by the serum of rabbits vaccinated intravenously with four weekly doses of homologous live culture, but was inactivated by mixing in vitro with serum of rabbits vaccinated with sterile loop fluid.

This toxin appeared similar to procholeragen A, which Finkelstein et al. stated was active when administered orally to baby rabbits together with a dialysable factor B. It was postulated (Ghosh, 1965) that most of the contradictions in the current reports on cholera toxins could be resolved if the active enterotoxin exists normally in an acid-stable but biologically inert form bound with a dialysable factor (probably lipid) that is easily dissociated by vibrionic and tissue enzymes. A sample of procholeragen A alone kindly supplied by 
Dr Finkelstein proved active in loops. Dr Finkelstein's team has independently confirmed its effectiveness in baby rabbits on direct intra-intestinal inoculation, and demonstrated its ability to cause dilatation of blood capillaries (Burrows, 1968). It is indeed hard to visualise how a patient can rapidly lose vast

TABLE V

Demonstration of enterotoxin in chloroform-sterilised intestinal fuid of infected rabbits by reinoculation of fluid into healthy rabbits

\begin{tabular}{|c|c|c|}
\hline $\begin{array}{l}\text { Test system } \\
\text { (animal; amount } \\
\text { of fluid; route } \\
\text { of injection) }\end{array}$ & Inoculum & $\begin{array}{l}\text { Number positive } \\
\text { number tested }\end{array}$ \\
\hline $\begin{array}{l}\text { Adult rabbit; } \\
2 \mathrm{ml} \text {; into } \\
\text { ileal loop }\end{array}$ & $\begin{array}{l}\text { Saline-chloroform } \\
\text { Loop fluid from rabbit infected with } V \text {. cholerae strain } 12 \mathrm{r} \\
\text { Loop fluid from rabbit infected with } V \text {. cholerae strain } 834 \\
\text { Loop fluid from rabbit infected with } V \text {. cholerae strain } 569 \mathrm{~B} \\
\text { Loop fluid from rabbit infected with } V \text {. cholerae strain } 12 \mathrm{r} \text {, } \\
\quad \text { + antibacterial serum } \\
\text { Loop fluid from rabbit infected with } V \text {. cholerae strain } 12 \mathrm{r} \text {, } \\
\quad \text { + antitoxic serum } \\
\text { Loop fluid from rabbit infected with } V \text {. cholerae strain } 12 \mathrm{r} \text {, } \\
\text { heated } 1 \text { hr at } 37^{\circ} \mathrm{C} \text {. } \\
\text { Loop fluid from rabbit infected with } V \text {. cholerae strain } 12 \mathrm{r} \text {, } \\
\text { heated } 30 \text { min. at } 56^{\circ} \mathrm{C} \\
\text { Loop fluid from rabbit infected with } V \text {. cholerae strain } 12 \mathrm{r} \text {, } \\
\text { formolised } \\
\text { Loop fluid from rabbit infected with } V \text {. cholerae strain } 12 \mathrm{r} \text {, } \\
\text { dialysed }\end{array}$ & $\begin{array}{l}0 / 18^{*} \\
4 / 4 \\
4 / 4 \\
2 / 2 \\
3 / 3 \\
0 / 3 \\
4 / 4 \\
0 / 3 \\
0 / 2 \\
4 / 4\end{array}$ \\
\hline $\begin{array}{l}\text { Baby rabbit; } \\
1.5 \mathrm{ml} \text {; intra- } \\
\text { duodenal }\end{array}$ & $\begin{array}{l}\text { Saline-chloroform } \\
\text { Loop fluid from rabbit infected with } V \text {. cholerae strain } 12 \mathrm{r} \\
\text { Loop fluid from baby rabbit infected with } V \text {. cholerae } \\
\text { strain } 12 \mathrm{r} \text {. } \\
\text { Loop fluid from baby rabbit infected with } V \text {. cholerae } \\
\text { strain } 12 \mathrm{r} \text {, heated } 30 \mathrm{~min} \text {. at } 56^{\circ} \mathrm{C}\end{array}$ & $\begin{array}{l}0 / 2 \uparrow \\
2 / 2 \\
4 / 6 \\
0 / 2\end{array}$ \\
\hline
\end{tabular}

* Number of loops showing fluid accumulation/number of loops tested.

$\uparrow$ Number of baby rabbits dead/number used for test.

amounts of potassium unless this or a similar toxin alters cell permeability throughout the body.

It is interesting that enteropathogenic $E$. coli, which can cause a severe choleraic diarrhoea in children (cholera infantum), and also in rabbit loops (Taylor, Maltby and Payne, 1958), has been shown to produce an enterotoxin with similar physical properties controlled by transferable genetic factors (Smith and Hall, 1968).

\section{SUMmary}

The clinical, morphological, biochemical and bacteriological characteristics of two methods for inducing a cholera-like condition in rabbits were evaluated. The infection in suckling rabbits was considered analogous in all essential respects to the natural disease in man, and the infection in ileal loops of adult 
rabbits duplicated the local pathology closely until excessive luminal pressure introduced artefacts. It appears that the loop method is better suited for immunological studies, but that the baby-rabbit infection will give more information on host-parasite interactions. An enterotoxin reproducing the manifestations of cholera was demonstrated.

These studies, under the guidance of Professor Robert Cruickshank, were subsidised by the Fleming Memorial Fund. The University Pathology Department prepared the tissue sections. The biochemical estimations were done in the Royal Infirmary, Edinburgh. The figures were made by the Medical Illustration Unit of the University, except the photomicrograph by Mr Ho Tat Seng, University of Malaya. The vibrio strains were kindly supplied by Dr B. I. Davies, Dr N. K. Dutta, Dr J. C. Feeley and Col. Sidney Gaines.

\section{REFERENCES}

Burrows, W.

1968. A. Rev. Microbiol., 22, 245.

Burrows, W., Elliot, Marion E., and HaVens, Isabelle

CohNheim, J.

1947. J. Infect. Dis., 81, 261.

CRUICKSHANK, R.

1889. Lectures on general pathology, London, vol. 2, p. 598.

DE, S. N.

1965. Handbook of medical microbiology, 11th ed., Edinburgh.

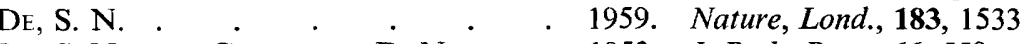

De, S. N., and Chatterje, D. N. . 1953. J. Path. Bact., 66, 559.

Dutta, N. K., AND HabBu, M. K. . 1955. Br. J. Pharmac., 10, 153.

Finkelstein, R. A., Norris, H. T., AND 1964. J. Infect. Dis., 114, 203. DUTTA, N. K.

FLOREY, H. W.

1933. J. Path. Bact., 37, 283.

Fresh, J. W., Versage, P. M., and 1964. Archs Path., 77, 529. REYES, $\mathrm{V}$.

Gangarosa, E. J., Beisel, W. R., Benyajati, C., Sprinz, H., and Piyaratn, P.

GHOSH, H. K.

1960. Amer. J. Trop. Med., 9, 125.

GoOdPasture, E. W. .

1965. Ph.D. Thesis, Univ. Edinburgh.

1969. Far East Med. J., 5, 53.

1923. Philipp. J. Sci., 22, 413.

HORN, R. C., J $\mathbf{J}_{\mathrm{R}}$.

1966. In Pathology, 5th ed., edited by W. A. D. Anderson, St Louis, vol. 2, p. 855.

ISSAEFF, AND Kolle, W. - . $\quad$. 1894. Z. Hyg. InfektKrankh., 18, 17.

Keusch, G. T., Atthasampunna, P., 1967. Proc. Soc. Exp. Biol. Med., 124, 822. ANd Finkelstein, R. A.

Lindenbaum, J., Greenough, W. B., 1965. Lancet, 1, 1081.

III, Oseasohn, R., Benenson, A. S., RIZVI, S., AND SAAD, A.

MAALøE, O.

Marston, A.

1955. Bull. Wld Hlth Org., 12, 769.

METCHNIKOFF, E.

MEYNELl, G. G., AND MAW, JoAN

Patnaik, B. K., AND GHosh, H. K.

SANARELli, G.

1962. Lancet, 2, 365.

1894. Annls Inst. Pasteur, Paris, 8, 529.

1968. J. Hyg., Camb., 66, 273.

1966. Br. J. Exp. Path., 47, 210.

1921. Annls Inst. Pasteur, Paris, 35, 745.

SCOTTI, T. M.

1966. In Pathology, 5th ed., edited by W. A. D.

Anderson, St Louis, vol. 1, p. 96.

Shrivastava, D. L., ANd White, P. B. . 1947. Ind. J. Med. Res., 35, 117.

Simith, H. W., ANd Hall, Sherla . 1968. J. Gen. Microbiol., 52, 319. 
Sprinz, H., Sribhibadh, R., Gangarosa, 1962. Amer. J. Clin. Path., 38, 43. E. J., Benyajati, C., Kundel, D., AND Halstead, S.

Taylor, Joan, Maltby, M. Patricia, 1958. J. Path. Bact., 76, 491. AND PAYNe, J. M.

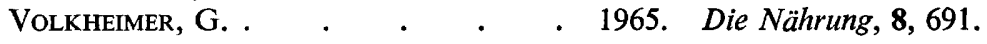

